\title{
Benediction Contribution towards Job Performance through Quality Work Employees at the University of Batam, Indonesia
}

\author{
Chablullah Wibisono ${ }^{1}$ \\ ${ }^{1}$ Batam University Lecturer, Batam, Indonesia \\ Correspondence: Priyono, Graduate Program Master of Management, Universitas of Bina Darma, Palembang, \\ Indonesia. Tel: 81-21-697-4878. E-mail: priyono.unu_sidoarjo@yahoo.com
}

Received: December 6, 2016

Accepted: December 19, 2016

Online Published: April 24, 2017

doi:10.5539/res.v9n2p179

URL: http://doi.org/10.5539/res.v9n2p179

\begin{abstract}
This study aims to identify and examine whether prayer intentions to contribute to the quality of work: Is ritual process contributes to the quality of work? Is a prayer accompanies efforts to contribute to the quality of work? Is prayer intentions to contribute to job performance? Whether the process rituals contribute to job performance, Do businesses contribute to job performance?

The research was conducted on the University's staff Batam totaling 193 people. University Batam pick the 16 courses 8 accredited B and $8 \mathrm{C}$. accredited university Batam has the facilities and the physical facilities are very adequate and equipped with two reliable Mosque and pray every Zohar and Asr prayer and diligent employees after prayers, whether her payer give contribution to job performance, work quality? Positive phenomenon is interesting to study the variable Benediction, Job Performance, quality Work. Data analysis was performed using the method Structural Equation Model (SEM).
\end{abstract}

Keywords: intention prayer, ritual process, business accompanying prayer, quality of work and job performance

\section{Introduction}

There are several factors that led prayers never granted. Among because sinners are done, or by eating food that is haram, or perhaps also prays never come true because God Desiring to replace what he asked with a better one in heaven and the afterlife. From Abu Hurairah he said: "The Prophet sallallaahu' alaihi wasallam told of a man who has long run due to the distance which he passes". So his hair was matted, tangled and dusty. The man raised his hands to the sky as he prayed: "O my Lord, O my God. Though, food of illicit goods, drinks from the unlawful, his clothing from the unlawful and fed with food that is illegitimate, then how God will let her prayer?" (Reported by Muslim, Ahmad, \& Tirmidhi). “And when my servants ask about me, then (answer), I am indeed close, I granted the request of people who pray, when he prayed to Me" (QS. Al-Baqarah, p. 186).

The research was conducted on the University's staff Batam totaling 193 people. University Batam pick the 16 courses 8 accredited B and $8 \mathrm{C}$. accredited university Batam has the facilities and the physical facilities are very adequate and equipped with 2 be relied Mosque and pray every Zohar and Asr prayer and diligent employees after prayers, whether her prayer give contribution to job performance, work quality? Positive phenomenon is interesting to study the variable Benediction, Job Performance, quality Work. Surely the target will never be reached if not accompanied optimal effort. Like people farming, it is the seed business. While prayer is a fertilizer. So prayer is accompanied by a business is like spreading fertilizer but never sowed so it will never harvest. Above all, the most important that prayer is the essence of worship (the ritual). As a servant of God whose main task is to worship him. Whoever is better will always get ridha-worship him. Anyone who earn his pleasure will be happy life both in this mortal world and the here after later and everlasting why a lot of people who always pray at mosque, at home but such does not have charitable contributions to the business, the quality of work and job performance? With this positive phenomenon interesting to be held Research entitled "Contributions of Prayer for work performance through quality employee at the University of Batam". Variables measured by three-dimensional prayer that intention Pray, Ritual Process, Business Accompanying Prayer, so that her problem can be formulated as follows, Problem Formulation:

1) Is the intention to pray to contribute to the quality of work?

2) Is the ritual process contributes to the quality of work? 
3) Is the attempt to accompany prayers contribute to the quality of work?

4) Is the intention to pray to contribute to job performance?

5) Does the ritual process contributes to job performance?

6) Does the business to contribute to job performance?

7) Is the quality of work contributes to job performance?

\section{Theoretical Basis}

\subsection{Theory of Prayer}

Regular prayer interpreted by the request of a servant to his Lord, pray ordinance is set in the Qur'an and Sunnah, aberrations can be categorized against polytheism and heresy. Dhikr usually interpreted to mean the praises of God, while contemplating the greatness of God through the sense contemplated asthma God thought so have dhikr productive effects that can improve the performance of a Muslim. Potential prayer, devotions and Illahiyah think is an asset that should be managed properly in the working embodiment achievement or righteous deeds (Tasmara, in Wibisono, 2002, p. 61). God bestow his gift to mankind with these two grand potential. An overflow which may not be given to any creature. God challenged the jinn and mankind to subdue firmament of heaven and promised that the genie and mankind will not be able to unless they have Sulthon, as in Qur'an letter Ar Rahmaan paragraph 33. Potential positive remembrance and, coupled with the potential for a positive think the results will be becomes larger. Conversely though Dhikr great potential, but is not accompanied by science, thought as a reflection of the ability of self, then the result will be less or grow away from the goal (Wibisono, 2002, p. 61).

As a Muslim who has a high appreciation of the achievements as well as the belief that work is worship, each individual Muslim should have a goal that this life will have value if they can be a godsend for the environment and natural surroundings. "Indeed, they are the ones who always hasten in (doing) good deeds, and they pray to us with hope and fear. They are the ones who humility to us" (Q.S. Al Anbiya, p. 9). Their stomachs are far away from the bed. As they pray to their Lord with fear and hope. They spend out of the sustenance which we have bestowed on them (Q.S. As Sajadah, p. 16). Pray as the beginning of the beginning, intended to give directions so that every act of charity, meet the criteria of appropriateness and balance, as a requirement of such errors. Often a person whose misfortune befalls and feel the depression is severe and causes also lose light and divine light, weather was black as Satan's temptation, then took the decision to find a short path to the road idolatry. Prayer is light and charity is bright. The meaning of prayer is fire and charity is heat. Between prayer and charity endeavors constitute one package, one breath that compound, can not be cleaved partially or fragmentation. Proverb that means, prayer without effort like a bow without the arrow (Wibisono, 2002, p. 63).

A special prayer, will encourage positive behavior and behavior among inner elf stood the "minds". Thus, all actions that are in the inner elf and human behavior will be influenced by the way of thinking is a mental process that gave birth to the inner image of yourself, or the meaning of environmental assessment as well as the emotional relationship between body and soul in a relationship with nature. By praying, meant to show the quality and the ability to perceive themselves to have a mental picture of the assumptions on which is none other than one part of the thinking process itself (Tasmara, in Wibisono, 2002). The prayer that gave birth to the optimism, moving themselves gallant attitude to performing. He is not afraid of difficulties, because in his conscience there is a belief that after the difficulties must have been no easy, as the Word of God: "For verily difficulty there is relief, the real hardship comes ease" (letter Al Insyiraah, pp. 5-6). "Pray to me I will certainly let you" (QSAl believer, p. 60). "Pray to your Lord with a humble heart and a soft voice. God does not love those who are beyond the limit. Do not mischief on the earth after God fix it. Pray to Him with fear and hope will not be accepted will be granted. God mercy is very close to those who do Good" (QS. Al A'raaf, pp. 55-56). "Those who do not pray to God, the wrath of the one God to him" (HR. At Tarmizi). "Prayer is the weapon of the believers and the pillar of religion and the light of the heavens and the earth" (HR. Al Hakim). "It is not a Muslim turned her face (begging) to God something petition, but will be granted his request it. Or in the fast give his or saved for another time" (HR. Imam Ahmad \& Al-Hakim, 1970). "Surely God is alive and charming, shy him from his servants if the servant lowered his hands, if not put him good in the hand" (HR. Ibnu Majah, Ibn Hibban, \& Al-Hakim, 1993; Wibisono, 2002, p. 65). Variable prayer can be lowered to three dimensions namely intention prayer, ritual process, business accompany prayer. 


\subsection{Theory of Quality of Work}

In the perspective of Islam, humans are not perfect whole. Although the Qur'an describes the man as being perfect. Perfection is inherent in man because of physiological conditions that distinguish the other God's creatures. In addition, the Lord gives intelligence capacity (sense) to man as a creature of his choice. The process of creation of mankind basically has the principles and objectives. Islam views the human being as a whole which includes process development, both physically and spiritually. Therefore, understanding the principles of Islam about the real human discuss four of them: the first, of human events in the view of Islam and the purpose of his life. Second, the properties of the original human being is part of God's attributes. Third, human beings fulfill their duty as the caliph and the final agreement between God and mankind (Wibisono, 2011, p. 136).

Although humans move dynamically four of the above actually illustrates the limitations of freedom and serving the rights and duties of human life by creators and other creatures. In this context man to take the test of life is to live with resignation or creative to make sense of the life of one of them to study and work. There is a difference between philosophical worldview fatalism (jabariyah) with the philosophy of free will (Qadarites) about the man who is free. Sunnatullah theology with philosophy Qadarites and temporal orientation in addition hereafter, also make Muslims productive in the field of economics and civilization (Nasution in Wibisono, 2011). Tawheed is taught in the community generally rububiyah monotheism taught by Ash'ari and commonly referred to as Ahlu Sunnah wal Jamaah (Wibisono, 2011, p. 136).

Tawheed rububiyah often accused of being the cause of human surrender to fate, then monotheism recommended Qur'an is monotheism uluhiyah who also taught the Prophet Muhammad. Tawheed uluhiyah teaches how to recognize only one God, whereas monotheism rububiyah considered as a way of working that removes the motive and performance. The quality of a person is determined by ninety percent attitude and ten percent by the science. While attitudes and behaviors are determined by values such as sincerity is a manifestation of the attitude of tawheed (Abdurrahim, the Muhammadiyah, in Wibisono, 2011, p. 15). In keeping with the above description, Islam assess religious belief is the heart of faith dimension. The theology contained in the last set of beliefs about reality, about the natural and supernatural desire, so that other aspects of the religion becomes coherent. Rituals and spiritual activities show obedience in human communion with the creator. The ritual process will be difficult to understand if these activities are outside the framework of trust containing the proposition that there is a powerful force to be worshiped (Wibisono, 2011, p. 137).

In addition to faith, in Islam there is sharia and morals. Basically, Islam is divided into three parts, namely faith, worship and mu'amalat, in which three parts were related to one another. Aqidah is a system of belief and the basis for sharia and morals. No Sharia and Islamic morality, without the Islamic Aqeedah (Ansari, in Wibisono, 2011). Ancok in Wibisono (2011) adds, although not exactly the same, belief dimension can be equated with faith, dimensions of religious practices aligned with the Sharia and moral dimension aligned with the practice. Dimensions beliefs or Islamic faith refers to how the level of Muslim belief to the truth of their religion, especially against the teaching of fundamental and dogmatic. In Islamic theology, the contents of the faith dimension concerning beliefs about God, angels, apostles, the book of God, heaven and hell, as well as the making up and qadar. Aqidah itself is basically embedded in man since azali (pre-birth). Aqidah be well maintained if a person's life is decorated with the planting of tawhid adequately. Conversely, if a person's life are decorated denial of the faith and Islam, monotheism someone questionable. Therefore, in order to aqidah someone maintained, then the person should get an explanation of the aqidah of the principal sources of the Qur'an and the Sunnah. With the right information about the faith, the promise of humans to recognize the power of God will be maintained. At this stage when crime awake, then one must equip it with the knowledge of aqidah (Wibisono, 2011, p. 137).

When a person presents a sound belief belief dimension into his life, often occurs in the inner practice that is individualized for instance, when a Muslim prays to God, he would feel close and vibrate in the presence of God, and plead for dialogue felt heartfelt promise when his prayer is granted. When a Muslim worshipers, it will be felt face, as if seeing God. Cling to the words in the same worship is meant to keep the commands of God outside of worship. Similarly, fasting, as the order of God despite weak physical condition, and remain firm establishment of the effects of fasting can increase spiritual energy to improve performance. One of the reasons of failure in fulfilling the basic needs of human life increasingly felt difficult is the lack of their determination in the process of actualizing religion itself. Given these circumstances, can be seen from the growth in unemployment is unstoppable and the quality of human life in poverty. Therefore, the idea is very urgent to rescue this situation is the need to ground the spiritual motivation. Efforts to make it happen as suggested Moeslim Abdurrahman in his Transformative Islam is the actualization of the theology of work. That is, people basically do not merely meet the basic needs of physical and biological. But theologically, to work for people is 
the actualization price and dignity themselves as being God's Majesty (Abdurrahman, in Wibisono, 2011, p. 138). With critical tone, he likens the animals foraging for encouragement hunger and thirst. Instead, people work because they have a bond that is nobler, because people in all aspects of his life dodging webs encircling the meaning of culture.

Working professionally means working diligentl accompanied by the multi-skills. Have high discipline, productive, creative, and innovative. A Muslim man was fully aware that the work performed is driven by the awareness to implement the obligations which the Lord commanded. Or in other words, professionalism which is based on the work of theology is the doctrine mu'amalat in employee performance. Reflecting the work ethic in the West, explained that the emergence of the term professionalism of today is not just the demands of time, but the fruit of the work of Max Weber reflective thinking about the Protestant ethic XVII century in Western Europe, particularly in Calvinist teachings. Weber proved in a study that religion gives strength to the emergence of entrepreneurial ethos. Thus, working wholeheartedly arising from motivation does not come from consumptive value, but by the motivation of the creative value called the work ethic. The above teachings are the basis of what Weber called "worldly asceticism" is a form of religious devotion which is implemented by working hard to fulfill the task of mundane as a sacred task for someone who feels getting calls and being elected (Rahardjo, in Wibisono, 2011, p. 139). This further raises the rationalization process that human work is not only driven by psychological needs but also a theological necessity to achieve happiness.

For Muslim Abdurrahman (in Wibisono, 2011, p. 139) it does not mean in all socio-economic context, the teaching will also give the same effect. In a study of the social sciences, which is trying to see the role or influence of religion on the cultivation of moral and ethical work, did show a positive situation. For example puritanical attitude, hard work, thrift, respect time, a willingness to postpone momentary pleasure for the sake of improving achievement, and so forth. The problem, which is a big question mark is Muslim Abdurrahman Can we create the conditions for the growth of the seeds of such a religious ethic. Here especially in the management of human resources today, in the sense of transcendence turn the work and at the same time prevent the alienation and dehumanization. Muslim assume that it can we make it happen, as long as we dare to accentuate orientation "Caliphate" than "reward". The aim is to foster the work as worship, and work not only as a life support (Abdurrahman, in Wibisono, 2011, p. 139). If understood carefully, then the orientation of the Caliphate refers to the character of the human beings who work. These characters correspond to the position of human as the representatives of God on earth, and this is what characterizes the purpose of employment and the influence of spiritual motivation in the fulfillment of human needs. No doubt that in the view of Islam foster the work ethic as a worship should focus on humans. Working for a Muslim is part of the religious orders that must be interpreted as muamalat activity to the creator so that the work displays quality performance in order to obtain optimal results. At least in the apostolic success stories need to be a role model, namely, how resilience works Khadija in trade by displaying a productive work ethic and a professional can help propaganda Messenger. But on the other side of the work environment should also be noted. So as to create a pleasant working climate, there is cooperation, tolerance and spirit of togetherness which is high for developing their business. A professional work ethos productive and competitive. So that he can combine the work ethic and ethos of science to improve their living standards. If it has been met, then the job satisfaction will be obtained pending performance based on an assessment of performance (Wibisono, 2011).

\subsection{Theory of Job Performance}

A basic principle of religious work performance should be reflected in the production system is Islamic, because production means the creation of benefits, as well as the consumption is the destruction of production. Production does not mean physically create something that does not exist, because no one can create matter. In terms of economic experts, which could be human just make stuff to be useful is called "generated". Fundamental principles that must always be considered in the production process is the principle of economic welfare. Even in the capitalist system there is a call for producing goods and services that are based on the principle of economic welfare. The uniqueness of the Islamic concept of economic prosperity lies in the fact that economic prosperity can not ignore the general welfare considerations concerning moral issues, education, religion and others. Economic prosperity in a modern economy is measured in terms of money. As Pigou said: "Economic welfare can be roughly defined as part of well-being that can be associated with a gauge of money". Materialistic modern economic welfare, it is necessary to limit the scope of the same subject (Mannan, in Wibisono, 2013). Man as vicegerent of God have been commanded to manage the Earth to prosperity and economic welfare. God says: "God who has created the heavens and the earth and what is between them in six days (QS. As Sajda, p. 4). As a consequence of human perfection as human beings it is required to perform the work. Excess God has given to man is in order to serve and work achievement. God says: "And we have honored 
the children of Adam, and we gave them a vehicle on land and at sea, and we gave them sustenance of good things and we have favored them from most beings, we have created in truth more" (QS. Al-Isra, p. 70).

Religious work performance contains elements liable trust, innovation and research for the development of science and technology. God says: "Verily, we have offered a mandate to the heavens and the earth and the mountains, so they are reluctant to have it and feel inadequate, but entrusted by man" (QS. Al Ahzab, p. 72). The ability of humans exploiting the potential of nature is showing the ability of human work performance on the delegation power of God which has been bestowed to humans. Allah says: "And we subjected the wind for Solomon, who travels in a time equal to a month's journey in the morning and the afternoon at a time when the same journey with a trip a month anyway. And we flow the molten copper for him and some of the devil worked in front of him (under his control) with the permission of their Lord. The genie was made what Solomon desired from high buildings and sculptures and platters (magnitude) such as ponds and pot still (located above the furnace)" (QS. Saba'verse, pp. 12-13). Humans are strongly encouraged to develop science and technology in order to ease to serve and worship God. Furthermore, humans are commanded to penetrate the space with the power of science and technology (Sulthon), so that people admired the creations of God in order to process a religious performance. Religious work performance always involves science and production processes, so that the quality of work performance are religious not the same as usual (Wibisono, 2013).

\section{Research Methods}

\subsection{Research Variable}

According Sugiyono (2001, p. 20), variable research is an attribute or trait or aspect of a person or object that has certain variations defined by the researchers to be learned and conclusions drawn. The variable is a trait that can have various values. Furthermore, it is stated that the variable is the symbol which has a numerical rating. So it is a symptom of variables or properties of an object that has a variation or different values with another object that is the focus of researchers to observe. In this study, the variables can be divided into independent variables (independent variables) are variables that affect, consisting of (X1) Intention Pray, (X2) Ritual Process, (X3) Enterprises. Other variable is the dependent variable (dependent variable) is the variable that is affected or which become due for their independent variables. In this study, there are two dependent variable is the intermediate variables (intervening variable) is (Y) Quality of Work, and the dependent variable (dependent variable) is ( $\mathrm{Z}$ ) Job Performance.

\subsection{Operational Definition}

Operational definition is intended to provide understanding of concretely adapted to the purpose and direction of research so that the variables of the study can be observed empirically. Operational definition is a scientific information that is used by researchers to measure a variable which is the translation of a concept. Variable needs to be defined operationally to make it easier to find a relationship between one variable to another variable and also facilitate measurement (Jonathan, 2007, p. 112).

\subsection{Types of Research}

This study is a survey research, the research take samples directly from the population. Judging from the problems studied, this study is the study of causality, which aims to analyze the relationship and influence (causal) of two or more phenomena through hypothesis testing. Cooper and Schindler (2003, p. 11) revealed that the study which was based on a theory or hypothesis which will be used to examine a phenomenon that occurs classified on the type of research explanatory. Explanatory study conducted a study of the relationship between two or more variables, then tried to explain the phenomena that occur.

\subsection{Population and Sample}

\subsubsection{Population}

The population is a collection of the whole object to be measured in the study (Cooper \& Schindler, 2003, p. 179). The population in this study were all employees of the University of Batam totaled 193 person.

\subsubsection{Samples}

Samples is an element of the population selected to represent the population in the study (Cooper \& Schindler, 2003, p. 82). In this study, sample size adapted to the analysis model used is Structural Equation Model (SEM). In this regard, the sample size for SEM using the model estimates the Maximum Likelihood Estimation (MLE) is 100-200 samples (Ghozali, 2005, p. 17), or as much as 5-10 times the number of parameters to be estimated. In this study population of 193 , calculated by formula Solvin obtained $n=193 /\left(1+\left(193 \times 0,05^{2}\right)\right)=130.19$ rounded $=131$ respondents. 


\subsubsection{Research Instruments}

The main instrument in this study was a questionnaire. Variable measurement is done by using a Likert scale. Measurement procedure as follows:

1) Respondents were asked to answer the common questions that will be used as the basis of whether the respondents included in the criteria or not.

2) Respondents were asked to state their level of agreement to a statement filed on the basis of the researcher's perception of each respondent. Answer consists of five options, namely: Strongly Disagree (STS), Disagree (TS), please Agree (CS), Agree (S), and Strongly Agree (SS).

3) Scoring to answer Strongly Agree (SS) is assigned the value 5, and so on downward to the answer Strongly Disagree (STS) is given a value of 1 .

Weights assessment of respondents' answers can be explained in Table 1 below.

Table 1. Weight value answer respondents

\begin{tabular}{cc}
\hline Answer & Value \\
\hline Strongly agree & 5 \\
Agree & 4 \\
Quite agree & 3 \\
Disagree & 2 \\
Strongly disagree & 1 \\
\hline
\end{tabular}

\subsection{Data Collection Procedures}

\subsubsection{Types and Sources of Data}

The method used in this research is quantitative method so that the data in the study is quantitative data. Quantitative data is data in the form of numbers, such as scale data measuring interval and ratio. The source of the data used in this study were obtained through:

1) Primary Data is data obtained directly from the respondents by distributing questionnaires. In addition, I also conduct surveys directly to the Campus of the University of Batam where the author conducted research.

2) Secondary Data, the data obtained by studying literature related to the issues to be studied further. Secondary data were obtained from references such as from books, the internet, journals and other resources to support this research. From the book obtained by theories of Intention Pray (X1), Ritual Process (X2), Enterprise (X3), the Quality of Work (Y) and Job Performance (Z), and other theories.

\subsubsection{Data Collection Technique}

The data collected in this study were divided into two ways, through field studies and literature.

\section{Data analysis method}

Data analysis was performed using the method Structural Equation Model (SEM). The software used for the structural analysis is AMOS version 22. There are seven steps involved in modeling SEM, namely:

1) The development of a theory-based model.

2) Preparation of flowcharts (path diagram).

3) Convert the flowchart into a series of structural equations.

4) Selection of input matrix and estimation techniques models built.

5) Assessing the possible problems of identification.

6) Evaluation criteria of goodness of fit.

7) Interpretation and modification of models. 
Table 2. Acceptance criteria a model

\begin{tabular}{cc}
\hline Goodness of Fit Index & Cut-off Value \\
\hline $\mathrm{X}^{2}$-Chi Square & expected to be small \\
Significance Probability & $\geq 0,05$ \\
RMSEA & $\leq 0,08$ \\
GFI & $\geq 0,90$ \\
AGFI & $\geq 0,90$ \\
CMIN/DF & $\leq 2,00$ \\
TLI & $\geq 0,95$ \\
CFI & $\geq 0,95$ \\
\hline
\end{tabular}

Source: Ferdinan (2006).

\subsection{Interpretation and Modification Model}

The last step is interpreting models and modify the model for the models that do not qualify testing. After the models in the estimation, residual be small or close to zero and the frequency distribution of the residual covariance must be symmetric. Hair et al. provide a guideline to consider whether or not a modification of a model is to look at the amount of residuals generated by the model. Safety limits for the residual amount is $5 \%$. If the residual amount is greater than $5 \%$ of all residual covariance generated by the model, then a modification should be considered. Furthermore, when it is found that the residual value generated by the model was quite large (>2.58), then the other way to modify is to consider adding a new channel to the model in the estimation. With a brief explanation: if a model is accepted, do interpretations of causality resulting pattern (estimated), is statistically significant and followed the underlying theory. Furthermore, the model can be modified to produce an alternative model (competing models) to be compared with the original model. Better models chosen after obtaining a theoretical justification.

\section{Results and Discussion}

\subsection{Research Result}

\subsubsection{Evaluation of Assumptions SEM}

Evaluation of the assumptions of normality SEM preceded by an evaluation to determine the normality of the data. The evaluation of the normality of the data. Analysis of normality of the data used to determine whether the critical obtained and collected have a normal distribution or not. Normality of the data used for the analysis kritisskweness value and the value of kurtosis. Analysis of the distribution of normality are indispensable if the number of data $(n)<100$ pieces, however, for a sample size of $>100$ was deemed necessary normality test. If the data is obtained normal distribution, then allowing implemented parametric analysis. For the evaluation of the normality test skwenees and kurtosis test. Skweness test used to view the skewness/heeling dissemination of data, while kurtosis to see kurtosis distribution data. According Suharyadi (2003, p. 117), the data has a spread has slanted/inclined when a critical value (c.r.) to greater than $\pm 3,00$. Data skweness said to have pointed deployment if critical value (c.r.) for kurtosis $>3.00$. According to Ferdinand (2006, p. 97), normal spread data can be declared if a critical value (c.r) for skweness and kurtosis are not greater than \pm 2.58 . In this study used the criteria according to Suharyadi.

\subsubsection{Determination Analysis with SEM}

In accordance with the purpose of the study to determine the effect Utilization Geographical Location, Process Ritual, Resource Organization, and quality of development work region, coupled with the hypothesis formulated in Chapter III, the data was analyzed using Structural Equation Modeling (Structural Equation Modelling=SEM) which is a set statistical techniques which allow tests that relatively complicated set of relationships simultaneously (Ferdinand, 2002; Solimun, 2004). 


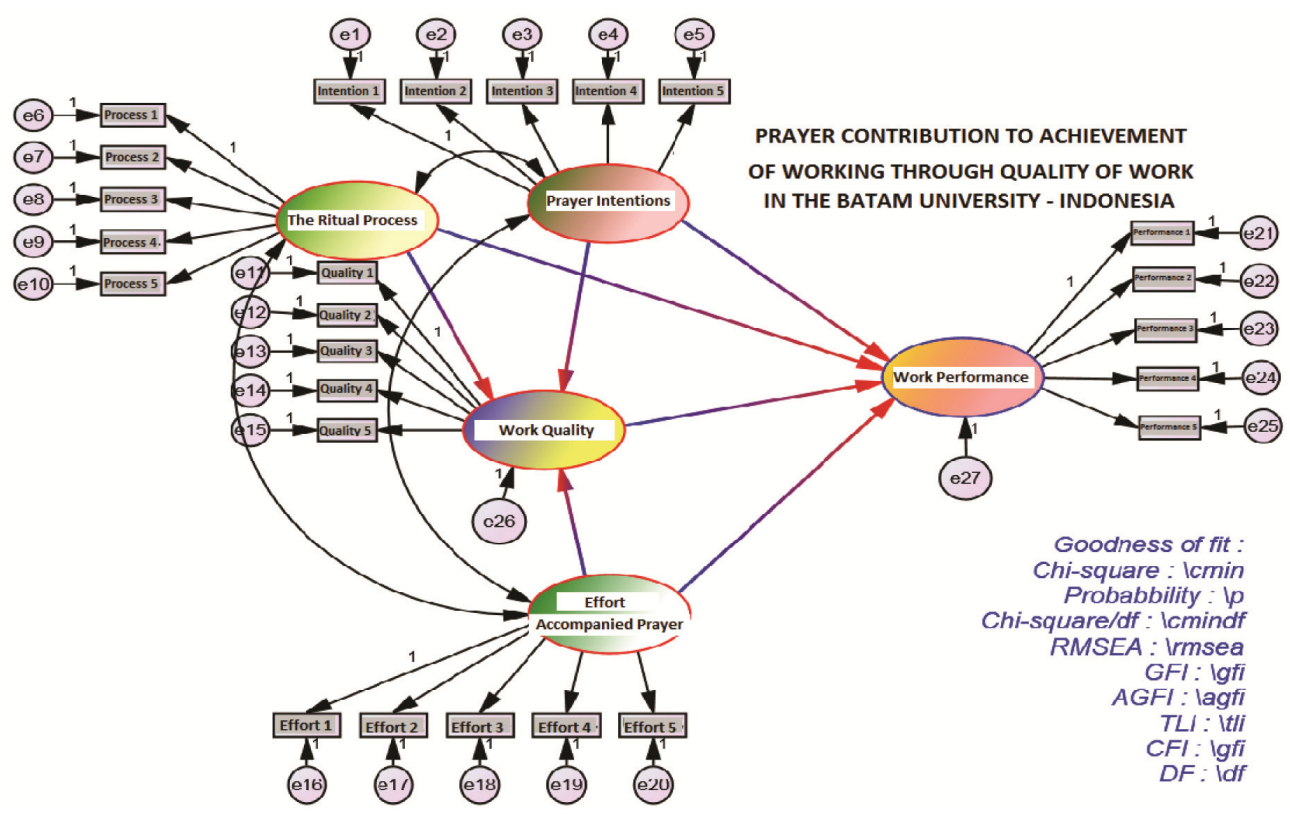

Figure 1. Conceptual framework

From the picture above, we can make the following equation model its structural: $\mathrm{H} 1: \mathrm{Y}=\gamma \mathrm{y} . \mathrm{X} 1 \mathrm{X} 1+\mathrm{e} 1$, direct

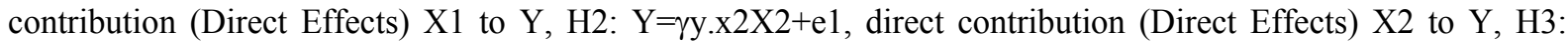
$\mathrm{Y}=\gamma \mathrm{y} . \mathrm{x} 3 \mathrm{X} 3+\mathrm{e}$, direct contribution (Direct Effects) X3 to $\mathrm{Y}, \mathrm{H} 4: \mathrm{Z}=\gamma \mathrm{z} . \mathrm{X} 1 \mathrm{X} 1+\mathrm{e} 2$, direct contribution (Direct Effects) X1 to Z, H5: $Z=\gamma z . \times 2 X 2+e 2$, direct contribution (Direct Effects) X2 to Z, H6: $Z=\gamma Z . \times 3 X 3+e 2$, direct contribution (Direct Effects) X3 to Z, H7: $Z=\beta z y Y 1+e 2$, direct contribution (Direct Effects) $Y$ to $Z$.

The model in the image above, further supplemented by relationships with the indicator every latent variable/item in question respectively, to be displayed models increasingly complete path diagram as shown in the following figure.

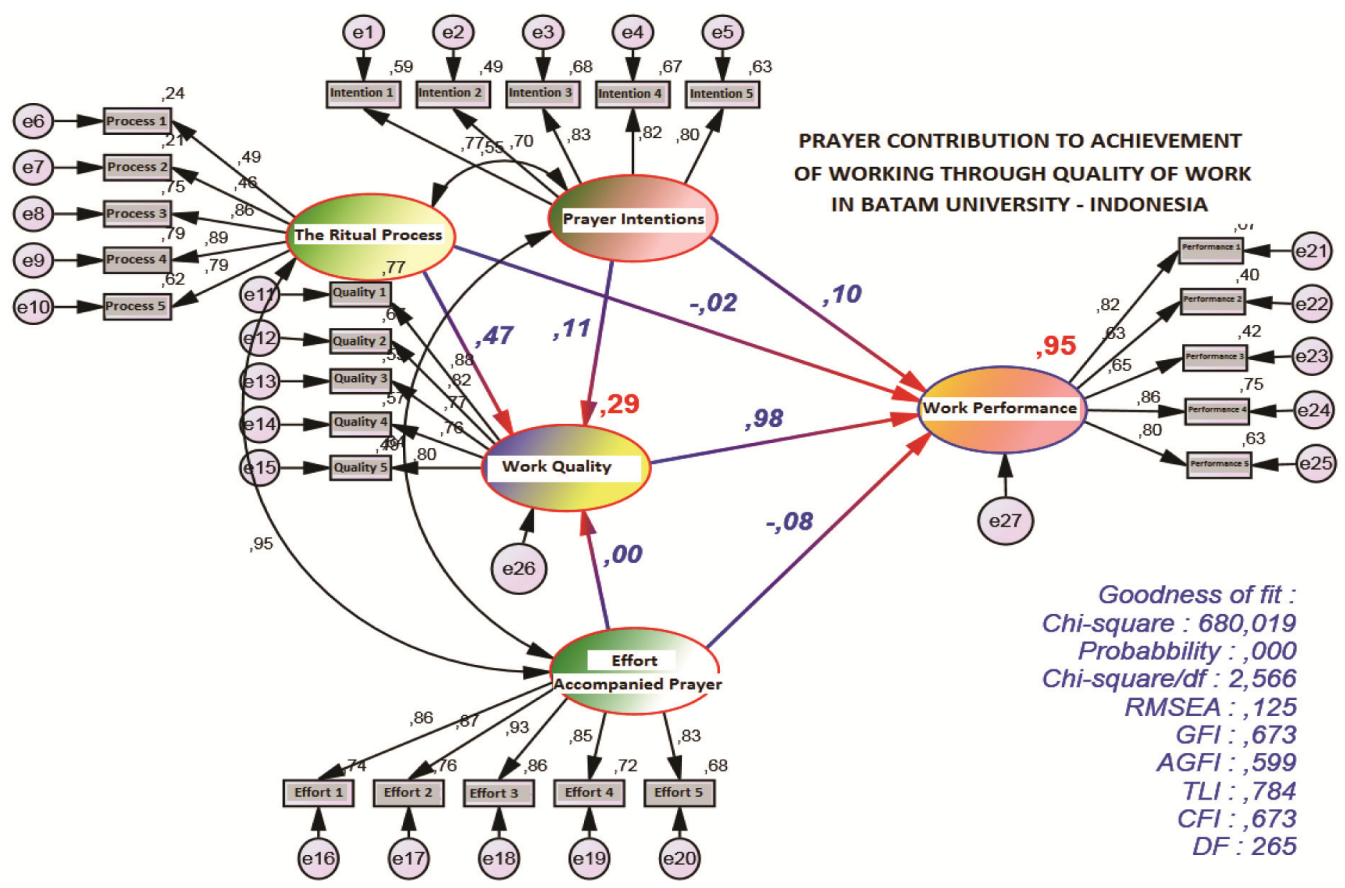

Figure 2. Full model variables (standardized) 
Based on the picture above, to do the analysis of the measurement model with parameter lambda, structural model analysis, determination analysis, goodness of fit for Contributions Prayer for work performance through the quality of employees at the University of Batam.

\section{Testing Analysis Model Parameter Measurement with Lambda $(\lambda \mathbf{i})$}

Parameter testing conducted is a test parameter lambda $(\lambda \mathrm{i})$. This test is intended to determine the validity of each indicator research. To test the parameters lambda $(\lambda \mathrm{i})$ used standardized value estimate (regression weight) in the form of loading factor. If the value of the standardized estimate (regression weight) $(\lambda \mathrm{i})>0.50$, $\mathrm{CR}>$ table $=2.000$, and Probability $<\alpha=0.05$, the lambda parameter loading factor $(\lambda \mathrm{i})$ the indicator was significant (Ferdinand, 2002, p. 97). This means that the indicator is valid. For testing purposes lambda parameters are shown following Tables loading loading factor/lambda $(\lambda \mathrm{i}), \mathrm{CR}$, Probability $(\mathrm{P})$.

Table 3. Standardized direct effects

\begin{tabular}{cccccc}
\hline & Pros & Business & Intention & Quality & Achievement \\
\hline Quality &, 472 &,- 003 &, 114 &, 000 &, 000 \\
Achievement &,- 015 &,- 080 &, 097 &, 984 &, 000 \\
\hline
\end{tabular}

Table 4. Regression weight (Lambda) indicators of prayer, job performance, quality of work

\begin{tabular}{cccccccc}
\hline & & & Estimate & S.E. & C.R. & P & Label \\
\hline Quality & $<---$ & Business &,- 004 &, 594 &,- 006 &, 995 & par_5 \\
Quality L & $<---$ & intention &, 135 &, 149 &, 903 &, 366 & par_6 \\
Quality L & $<---$ & Pros &, 850 & 1,012 &, 840 &, 401 & par_24 \\
Achievement & $<---$ & Intention &, 092 &, 068 & 1,351 &, 177 & par_1 \\
Achievement & $<---$ & Quality &, 784 &, 082 & 9,507 & $* * *$ & par_2 \\
Achievement & $<---$ & Business &,- 072 &, 265 &,- 272 &, 786 & par_3 \\
Achievement & $<---$ & Pros &,- 022 &, 454 &,- 048 &, 961 & par_4 \\
\hline
\end{tabular}

Table 5. Standarized regression weight (Lambda) prayer indicator, work performance, work quality

\begin{tabular}{cccc}
\hline & & & Estimate \\
\hline Quality & $<---$ & Business &,- 003 \\
Quality L & $<---$ & Intention &, 114 \\
Quality & $<---$ & Pros &, 472 \\
Achievement & $<---$ & Intention &, 097 \\
Achievement & $<---$ & Quality &, 984 \\
Achievement & $<---$ & Business &,- 080 \\
Achievement & $<---$ & Pros &,- 015 \\
\hline
\end{tabular}

The three tables above it can be seen that almost all indicators of latent variables exist that have standardized estimate (regression weight) in the form of loading factor or lambda $(\lambda i)>0.50$, the critical value $C R>2,000$ and has a probability of less than $0.05(* * *)$. Thus we can say that the standards mentioned above, then the latent variable indicator is valid/significant, but which do not fit the above standard indicator of the latent variable is invalid/significant. Based on the above three tables can be analyzed determination/contributions as follows:

a) Contributions latent variables Intention to Pray against latent variables Quality Work has standardized estimate (regression weight) of 0.114 with $\mathrm{Cr}$ (Critical ratio=identical to the value t-test) of 
0.903 on a 0.366 probability value $\mathrm{CR}=0.366<2.00$ and Probability $=0.366>0.05$ indicates that the contribution of the latent variables Prayer intention to Work Quality latent variable is positive not significant. Understanding the intention in prayer by the employees to understand the Hadith of Umar bin Al Khottob, he said that he heard the Prophet sallallaahu' alaihi wa sallam said, "Verily, every practice depends on his intentions. And everyone will get what he intended. Who emigration due to God and His Messenger, hijrah to God and His Messenger. Who emigration due to search the world or because the woman is married, then his emigration to the goal" (HR. Bukhari \& Muslim, 1970).

b) Contribution latent variable to variable latent Ritual Process Quality Work has standardized estimate (regression weight) of 0.472 , with $\mathrm{Cr}$ (Critical ratio=identical to the value t-test) of 0.840 on a probability $=\mathrm{CR}$ value $0.840<2.000$ and Probability $=.401>0.05$ indicates that the contribution of the latent variable to variable latent Ritual Process Quality Work is positive not significant. The process of ritual prayer should machination', carried out in accordance Sunnah postulate on the Qur'an and Hadith that the process not contribute significant ritual. A special prayer', will encourage positive behavior and attitudes between concerned stood the "minds" (Wibsono, 2002).

c) Contribution of Business latent variables Accompanying Prayer against latent variables Quality Work has standardized estimate (regression weight) of- 0,003 with $\mathrm{Cr}$ (Critical ratio=identical to the value t-test) of $-0,006$ in probability $=0.995$ Values $C R=-0.006<2.000$ and Probability $=0.995>0.05$ indicates that the contribution of the latent variable effort against latent variables Quality of Work is a significant negative. By praying, meant to show the quality of work and the ability to perceive themselves to have a mental picture of the assumptions on which is none other than one part of the thinking process itself (Frankl, 2002), the employee indicated in doing so less can not afford improve the quality of work.

d) Contributions latent variables Prayer Intention to Work Performance latent variables have standardized estimate (regression weight) of 0.097 with $\mathrm{Cr}$ (Critical ratio=identical to the value t-test) of 1.351 on a probability $=0.797$. CR value $1.351<2.000$ and Probability $=0.177>0.05$ indicates that the contribution of the latent variables Prayer Intention to Work Performance latent variable is positive not significant. Prayer is light and charity is bright. The meaning of prayer is fire and charity is heat as a consequence of human perfection as human beings it is required to perform the work. Excess God has given to man is in order to serve and work achievement. God says: "And we have honored the children of Adam, and we gave them a vehicle on land and at sea, and we gave them sustenance of good things and we have favored them from most beings we have created in truth more" (QS. Al-Isra, p. 70).

e) Contribution to the latent variable Ritual Process Work Performance latent variables have standardized estimate (regression weight) amounted to -0.015 , with $\mathrm{Cr}$ (Critical ratio $=-0.048$ identical to the value $\mathrm{t}$-test) of -0.048 on probability $=0.961$. CR value $0.048<2.000$ and Probability $=0.961>0.05$ indicates that the contribution of the latent variables Ritual Process against latent variables Job Performance is a significant negative. Religious work performance contains elements liable trust, innovation and research for the development of science and technology. Contribution of the ritual process should not be ignored in relation to job performance, so process rituals (worship) in the prayer can not contribute in job performance then noticed, word of God: "Verily, We have offered a mandate to the heavens and the earth and the mountains, then they are reluctant to have it and feel inadequate, but entrusted by man" (QS. Al Ahzab, p. 72).

f) Contribution of Business latent variables Accompanying Prayer against latent variables Job Performance has standardized estimate (regression weight) amounted to -0.080 , with $\mathrm{Cr}$ (Critical ratio=identical to the value t-test) of -0.272 on probability $=0.786 . \quad \mathrm{CR}-0.272<2.000$ and Probability $=0.786>0.05$ indicates that the contribution of the latent variables Enterprises to Work Performance latent variable is not significant negative. Between prayer and charity endeavors constitute one package, one breath that compound, can not be cleaved partially or fragmentation. Proverb that means, prayer without effort like a bow without an arrow, the intention of praying is done less than the maximum employee to improve work performance. Humans are strongly encouraged to develop science and technology in order to ease to serve and worship God. Furthermore, humans are commanded to penetrate the space with the power of science and technology (Sulthon), so that people admired the creations of God in order to process a religious performance. Religious work performance always involves science and production processes, so that the quality of work performance are religious not the same as usual. 
g) Contribution to the Quality of Work latent variable latent variables Job Performance has standardized estimate (regression weight) of 0.984 , with $\mathrm{Cr}$ (Critical ratio=9.507 identical to the value t-test) of 9.507 on a probability $=* * *$. CR value $9.507>2.000$ and Probability $=* * *<0.05$ indicates that the contribution of the latent variables Quality of Work against latent variables Job Performance is significantly positive. Working professionally means working diligently (hard worker) accompanied by the multi-skills (smart worker). Have high discipline, productive, creative, and innovative. A Muslim man was fully aware that the work performed is driven by the awareness to implement the obligations which the Lord commanded. So when a Muslim prays to God, he would feel close and vibrate in the presence of God, and plead for dialogue felt heartfelt promise when his prayer is granted. Quality of work is influenced by his prayer so as to have a positive contribution to job performance.

\subsubsection{Analysis Goodness of Fit}

Based on test criteria, Chi-square $(\chi 2)$, Relative Chi-square $(\chi 2 / \mathrm{df})$, RMSEA, GFI, AGFI, TLI and CFI at the top and Goodness of Fit value processing results Amos for Windows version 22.0, as shown in the picture above, it can be prepared the following table.

Table 6. Evaluation of goodness of fit

\begin{tabular}{cccc}
\hline Goodness of Fit Index & Cut-of Value & Model result & Information \\
\hline Chi-square $\left(\chi^{2}\right)$ & Expected to be small & $680,019^{+}$ & Marginal \\
Relatitive Chi-square $\left(\chi^{2} / \mathrm{df}\right)$ & $\leq 3,00$ & $\left.2,566^{*}\right)$ & Good \\
Probability & $>0,05$ & 0,00 & Not good \\
RMSEA & $\leq 0,08$ & 0,125 & Not good \\
GFI & $\geq 0,90$ & $0,673^{+)}$ & Marginal \\
AGFI & $\geq 0,90$ & 0,599 & Not good \\
TLI & $\geq 0,94$ & $0,784^{+}$ & Marginal \\
CFI & $>0,94$ & $0,673^{+)}$ & Marginal \\
DF & & 265 & good \\
\hline
\end{tabular}

*) Meet Goodness of fit.

+ ) Marginal.

Noting the cut-of-value and goodness of fit of model results in Table above shows all of the criteria are not met eight criteria were used. Criteria fulfilled is Relatively Chi-square ( $\chi 2 / \mathrm{df})$ and DF, while the marginal is GFI, TLI and CFI. Because the two said to be good and 3 models are marginal from the eight criteria required, then the above model can be expressed as a good model (Solimun, 2002, p. 80; Solimun, 2004, p. 71). For it is not necessary do modification by correlating an error has Modification Index (MI) $>8,000$ in order to improve the goodness of fit.

\section{Analysis of the Measurement Model of Determination/Contributions}

The following analysis by the coefficient Measurement Model Prayer, Job Performance, Quality Work Ritual Process. Analysis measurement model with determination is used to determine the contribution of exogenous variables on endogenous variables. For this analysis used Square Multiple Correlation. Multiple Correlation could be Square magnitude seen in the following table.

Table 7. Squared multiple correlations: group number 1-Default model

\begin{tabular}{cc}
\hline & Estimate \\
\hline Quality &, 291 \\
Achievement &, 953 \\
\hline
\end{tabular}


Square Multiple Correlation that their respective values for Quality of Work $=0.291$, for Job Performance $=0,953$ as shown in the table above. According to Ferdinand (2002, p. 114), Square Multiple Correlation values for the variables Quality of Work R2 identical to R2 $=0.291$ at the SPSS amounted to 0.291 . Determination magnitude Square Multiple Correlation is a value to a variable Quality of Work times $100 \%=0.291 \times 100 \%=29.10 \%$. Thus it can be stated that the changes to the Quality of Work influenced by intention Pray, Ritual Process and Business Accompanying Prayer of $29.10 \%$. For Job Performance R2 $=0.953$ then the magnitude of determination $=0.953 \times 100 \%=95.30 \%$. Thus it can be stated that the changes work achievement is influenced by intention Pray, Ritual Process and Business Accompanying Prayer and Work Quality of 95.30\%.

\section{Conclusion}

1) The contribution of latent variables Prayer Intention to Work Quality latent variable is not significant positive.

2) The contribution of latent variables Ritual Process Quality Work against latent variable is not significant positive.

3) Contribution of Business latent variables Accompanying Prayer against latent variables Quality of Work is a significant negative.

4) Contributions latent variables Prayer Intention to Work Performance latent variable is not significant positive.

5) Contributions to the latent variables Ritual Process Work Performance latent variable is not significant negative.

6) Contributions latent variables Accompanying Prayer Enterprises to Work Performance latent variable is not significant negative.

7) Contributions latent variables Quality of Work towards Job Performance latent variables are significant positive.

\section{Suggestion}

1) In prayer must be intended for God fervently and sincerely implemented.

2) Make the process of praying according to the guidance of the Sunnah.

3) Prayer and business are inseparable, each prayer must be accompanied by prayer, as the Word of God: "God does not change the state of a people so that they change the existing situation on themselves" (QS. Ar. Rad, p. 11).

4) In the prayer must be done sincerely in accordance Word of the Prophet: "O people, if you ask God Almighty, ask his immediate presence with full confidence that your prayer will be granted, because God will not grant do a coming out of the hearts of the heedless" (HRAhmad).

5) In order Ritual Process positively contributed significantly to the work achievement, done by taking ablution, overlooking qiblah letter read read Asamul Husna, then we say the phrase unity, the statement will express our faith in Allah Subhanahu wa ta'ala. We declare that God. The Supreme single, omnipotent, there is no partner for Him, and others.

6) It must be accompanied by a business, according the Word of God: "Work (try to) you, and Allah and His messenger and the believers will see your work (effort)" ... (QS. At Tawbah, p. 105).

7) Quality of Work in order to always give a significant positive contribution to the achievement of a religious Work involving science and production processes, so that the quality of work performance are religious not the same as usual.

\section{References}

Cooper, R. D., \& Pamela, S. S. (2003). Business research methods (8th ed.). New York: Mc. Graw-Hill/Irwin.

Ferdinand, A. (2002). Structural Equation Modeling in Management Research (Issue 2). Semarang: BP. UNDIP. Ferdinand, A. T. (2006). Methods of Management Research. Semarang: BP Undip.

Frankl, V. E. (1992). Man's search for meaning: An introduction to Logotherapy (L. Use, Trans.). Boston: Beacon Press.

Frankl, V. E. (2004). Search for Meaning of Life, Man's Search for Meaning (H. D. Lala, Trans.). Bandung: Nuance. 
Frankl, V. E. (2008). Optimism in the Midst of Tragedy: Logotherapy Analysis (H. D. Lala, Trans.). Bandung: Nuance.

Ghozali, I. (2005). Application of multivariate analysis using SPSS. Semarang: Diponegoro University Publishers Agency.

Jonathan, S. (2007). Path Analysis with SPSS for Business. Publisher Andi, Yogyakarta.

Ministry of Religious Affairs. (1994). Qur'an and Translation. Jakarta: Restu Bumi-Indonesia.

Solimun. (2002). Multivariate Analysis Structural Equation Modeling (SEM) lisrel and AMOS. Faculty of Mathematics and Natural Sciences, Universitas Brawijaya, Malang.

Solimun. (2006). Structural Equation Modeling Approach PLS and SEM Application Software Smart PLS and Amos. Undiknas Denpasar.

Sugiyono. (2001). The method of administration. Bandung: Alfabeta.

Suharyadi, \& Purwanto, S. K. (2003). Statistics for Economics \& Finance Modern. Publisher Salemba Four, Jakarta.

Wibisono, C. (2002). Dissertation "Influence of Spiritual Motivation on Employee Performance in Manufacturing Sector Sub Batamindo Batam”. Universitas Airlangga-Surabaya-Indonesia.

Wibisono, C. (2013). Effect of Motivation Mu'amallat (Works and Produce, Needs Secondary, Primary Needs) Job Performance of the Religious. Ijtihad Journal, 13(2).

Wibisosno, C. (2011). The Role of Spiritual Motivation and Work Ethics in Fulfillment Primer. Ijtihad Journal, $11(1)$.

\section{Copyrights}

Copyright for this article is retained by the author(s), with first publication rights granted to the journal.

This is an open-access article distributed under the terms and conditions of the Creative Commons Attribution license (http://creativecommons.org/licenses/by/4.0/). 